\title{
21. CLIMATIC CHANGE: CONTROL OF CARBONATE PLATFORM DEVELOPMENT (EOCENE-MIOCENE, LEG 133, NORTHEASTERN AUSTRALIA) ${ }^{1}$
}

\author{
T.C. Brachert, ${ }^{2}$ Ch. Betzler, ${ }^{3}$ P.J. Davies, ${ }^{4}$ and D.A. Feary ${ }^{5}$
}

\begin{abstract}
Leg 133 of the Ocean Drilling Program (ODP) dealt with the geologic evolution of the Great Barrier Reef Province off northeastern Australia. Sites 824 and $811 / 825$ on the western Queensland Plateau encountered crystalline basement covered by neritic carbonates ranging in age from the middle Eocene to early middle Miocene. Microfacies analysis (MF) confirmed the presence of MF-types, which can be related to (1) tropical platforms (chlorozoan association, MF1 and MF2) and (2) shelf environments of subtropical and temperate latitudes (bryomol association, MF3 and MF4). Chlorozoan limestone is characterized by scleractinians, coralline algae, foraminifers, green algae, and bioclasts. Muddy, bioclastic lithologies with miliolid and large foraminifers were interpreted to represent lagoonal environments (MF1). Well-washed grainstones and rudstones with abundant corallinacean algae and scleractinians probably have accumulated in a fore-reef setting (MF2). The bryomol carbonates are poorly lithified bryozoan grainstones and rudstones that are similar in composition and character to sediments currently forming on the New Zealand shelf. In MF4, bryozoans show all grades of mechanical infestation and may constitute $70 \%$ of the grains, whereas echinoderm remains and foraminifers are subordinate. Most intraparticle porosity has been filled in with a planktonic foraminifer wackestone, but interparticle voids are empty. This textural inversion has been interpreted to indicate winnowing of sediment during lowstands of sea level. Cementation is virtually absent, except for large syntaxial overgrowths on echinoid spines and plates. In MF3, larger foraminifers and corallinacean algae are abundant. Because of the occurrence of few Halimeda and an extensive early marine cementation, we interpreted these deposits as "subtropical." The vertical succession of climatically significant MF-types demonstrates late Oligocene cooling and early Miocene warming. These data are in line with the published temperature curves for the northeastern Australia region.
\end{abstract}

\section{INTRODUCTION}

Since the end of Eocene time, the Australian continental plate has drifted northward from high latitudes into the tropics (Davies et al., $1987,1989)$. One of the goals of Leg 133 was to document this latitudinal drift recorded in neritic skeletal carbonates, because they are considered environmentally sensitive with respect to climate, ocean fertility, and global variations in sea level (Lees and Buller, 1972; Hallock and Schlager, 1986; Scoffin, 1986; Collins, 1988; Nelson, 1988; Nelson et al., 1988; Reijmer et al., 1988; James and von der Borch, 1991). This study aims to test the validity of the paleotemperature curve developed for southwestern Pacific Ocean surface waters (Feary et al., 1991).

\section{SITE SETTING}

Modern cool-water carbonates form in areas of low terrestrial influx, such as submarine plateaus or along subdued coasts having no significant riverine influx and open-ocean conditions (Nelson et al., 1988; James and von der Borch, 1991). Thus, the isolated Queensland Plateau was a potential area for the formation of skeletal cool-water carbonates under appropriate climatic conditions. Two drilling transects were chosen to connect the Queensland Plateau (QP) with the modern Great Barrier Reef (GBR) off northeastern Australia and the submarine Marion Plateau (MP) (Fig. 1). The Marion Plateau lies directly east of the central Great Barrier Reef. The present surface forms a deeper-water extension of the Australian shelf, with water

\footnotetext{
${ }^{1}$ McKenzic, J.A., Davies, P.J., Palmer-Julson, A., et al., 1993. Proc. ODP, Sci. Results, 133: College Station, TX (Ocean Drilling Program).

${ }^{2}$ Institut für Geowissenschaften, Saarstr. 21, D-65 Mainz, Germany.

${ }^{3}$ Geologisch-Paläontologisches Institut, Johann Wolfgang Goethe-Universität Frankfurt, Senckenberganlage 32-34. D-6000 Frankfurt, Germany.

${ }^{4}$ Department of Geology and Geophysics, Edgeworth David Building, University of Sydney, Sydney, Australia 2006.

${ }^{5}$ Division of Marine Geosciences, Bureau of Mineral Resources and Geophysics, P.O. Box 378. Canberra City, ACT 2601, Australia.
}

depths ranging from about $100 \mathrm{~m}$ along the western border to $500 \mathrm{~m}$ along the eastern margin before it merges with the Townsville Trough and deep waters in the south. The Queensland Plateau is an isolated, positive feature having a mean water depth of $1100 \mathrm{~m}$. The plateau is slightly tilted to the northwest, with steeper slopes in the south. According to seismic sections, the margin of the plateau is controlled by normal faults (Davies, McKenzie, Palmer-Julson, et al., 1991). Drilling at Sites 824 and $811 / 825$ took place on the western part of the Queensland Plateau. Site 824, at a depth of approximately 1004 $\mathrm{m}$, is in a slightly more distal position with respect to ancient carbonate platforms than Sites $811 / 825$, which are in a water depth of approximately $938 \mathrm{~m}$ (Fig. 1). Although these sites are only $35 \mathrm{~km}$ apart, they are situated on different fault blocks east and west of a recent reef in windward and leeward positions, respectively (Davies, McKenzie, Palmer-Julson, et al., 1991).

\section{MATERIAL AND METHODS}

Samples were taken from lithified cores on board the JOIDES Resolution. Thin sections were prepared from lithified carbonates for petrographic studies. Microfacies types were established using the point-counting method (grain-bulk) described by Flügel (1982). Counting included skeletal particles, cement, and open porosity. The lithologic column was established from the drilling depth data of several holes and from downhole logging measurements (combined velocity/resistivity log; see Jackson, this volume), because recovery was low in most of the lithified carbonates penetrated (short intervals per core or isolated pieces only). Methods and procedures used for biostratigraphical dating are described in Betzler and Chaproniere (this volume), Betzler et al. (this volume), and Davies, McKenzie, Palmer-Julson, et al. (1991).

\section{DESCRIPTION OF SITE 824}

Site 824 bottomed in metamorphic continental basement after penetrating $401.9 \mathrm{~m}$ of pure carbonate sediments and rocks, which 


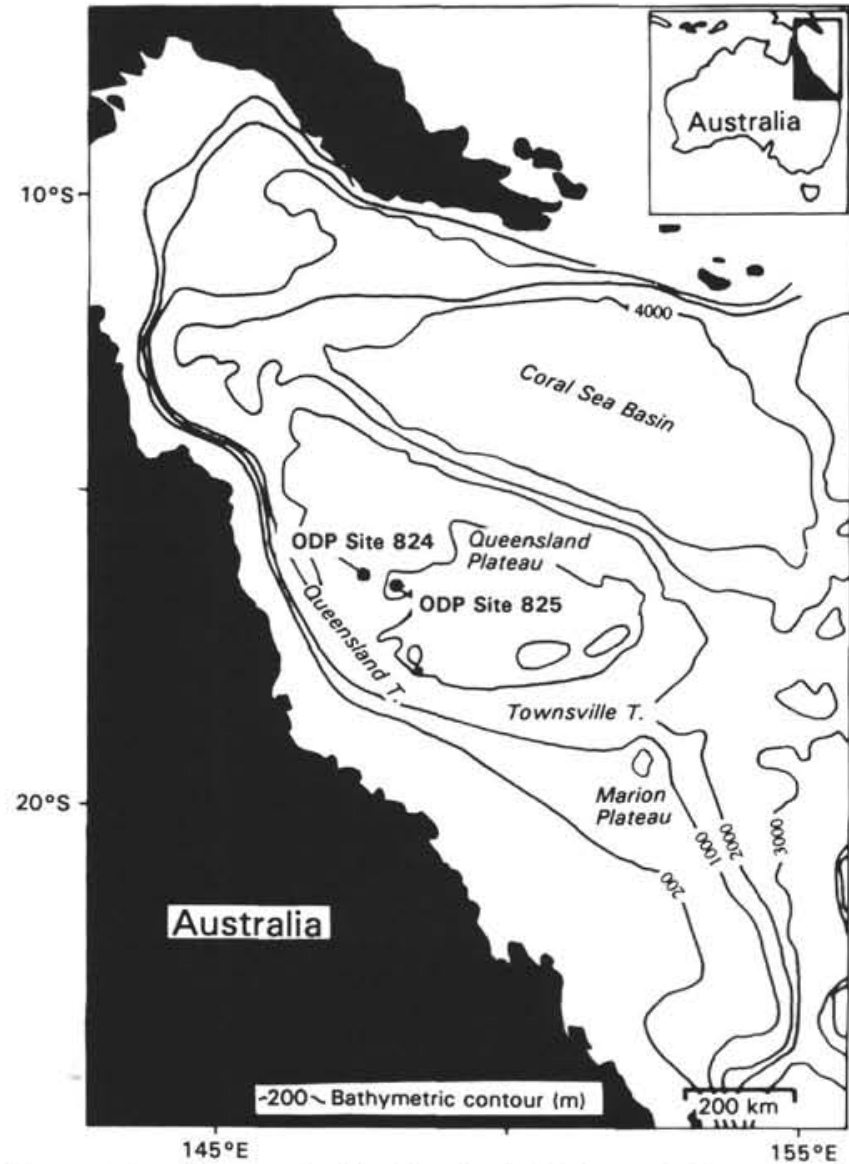

Figure 1. Locality map showing the principal bathymetric features of the northeastern Australian continental margin and Sites 824 and 825 (811).

were deposited in a pelagic, periplatform, and shallow-water carbonate environment. This sedimentary succession was divided into lithostratigraphic units by Davies, McKenzie, Palmer-Julson, et al. (1991, Fig. 2). The lithostratigraphic subdivision of the pelagic sequence was established on the basis of the variable proportions of periplatform sediments and discrete layers of redeposited, shallow-water-derived coarse material.

The upper $242.3 \mathrm{~m}$ below seafloor (mbsf) consists of unlithified sediments that were divided into four lithostratigraphic units (Units I-IV). Except for a thin layer of lithified carbonate found at 135.5 mbsf, these sediments are periplatform oozes and sand-fraction calciturbidites. The sediment composition is a mixture of $40 \%$ to $60 \%$ of bank-derived, unknown particles and variable proportions of planktonic organisms. Unit I represents two upward-fining packages 45 to $50 \mathrm{~m}$ thick. The lower part of each package is a thick, homogeneous interval of redeposited bioclastic packstone, whereas the upper parts of each package are alternating thin layers of redeposited particles and periplatform ooze. Unit II consists of numerous discrete layers of bioclastic packstone and periplatform ooze. Unit III is represented by a lithified bed of brown to dark-gray, well-cemented bioclastic packstone and rudstone. Allochems are fragments of corals, fragments of corallinacean algae/foraminifer crusts, and entire foraminiferan nodules, embedded in a bioclastic (mainly larger foraminifers, some mollusks) packstone matrix. This is interpreted to have been deposited in a fore-reef environment. Unit IV consists of light gray nannofossil ooze and chalk. Interbeds of calciturbidites (bioclasts: corals, coralline algae, large foraminifers, mollusks, echinoids) occur in the uppermost part of the unit.

The interval described here begins below $242.3 \mathrm{mbsf}$. It consists of weakly cemented carbonate deposits that were analyzed in thin section
(Units V and VI). Unit V is characterized by a shallowing-upward section of tropical neritic deposits, which are interpreted to have been deposited in fore- and back-reef environments. Unit V consists of skeletal packstone and rudstone; bioclasts derive from corallineencrusted corals, mollusks, echinoids, and larger foraminifers. Entire rhodoliths and some quartz grains occur at some levels. In the upper part, beds of white foraminifer chalk indicate deepening. Unit VI consists of white bioclastic rudstone. Fragments of branching bryozoans clearly dominate (average $50 \%$ ) indeterminable bioclasts, echinoderms, corallinaceans, and mollusks. Small azooxanthellate scleractinians were recorded by Davies, McKenzie, Palmer-Julson, et al. (1991).

At 401.9 mbsf, a deeply weathered, orange-brown skapolithe that grades downward into unweathered metasedimentary basement is present. Basement rocks are described in detail by Feary et al. (this volume).

\section{DESCRIPTION OF SITES 811/825}

The lithostratigraphy used here was combined from the drilling and logging results at Sites 811 and 825 , because the position of both sites is almost identical and because coring at Site 825 began at a depth of 379 mbsf downward (Fig. 2). The upper half of the sedimentary sequence is dominated by periplatform oozes and chalks that can be differentiated on the basis of their variable content of bank-derived carbonate particles. Abundant calciturbidites were found in the first $10 \mathrm{mbsf}$ and from 17.2 to $32.3 \mathrm{mbsf}$ downward (Subunits IA, IC), whereas fine-grained, bank-derived particles dominate from 32.3 to 70.0 mbsf (Subunit IIA). The sequence below this depth is characterized by white nannofossil oozes with foraminifers and foraminifer oozes with nannofossils. In Unit III, white calcareous ooze and chalk with nannofossils and foraminifers alternate with unlithified to partially lithified bioclastic packstone and floatstone. The unit has been interpreted to represent periplatform ooze and chalk alternating with several layers of calciturbidites and debris flow deposits.

Below $305.4 \mathrm{mbsf}$, recovery decreases to a minimum of several calcareous pebbles per core. In comparison to the somewhat better recovery at Site 811, the unit (Unit IV) consists of bioclastic packstone, grainstone, and rudstone (which presumably was deposited in a fore-reef environment). Bioclasts mainly derive from benthic foraminifers, corallines, and corals. Below 355 to $408.4 \mathrm{mbsf}$, there was no recovery. From 408.4 mbsf downward, the lithological succession is documented by $5 \%$ recovery. Unit VI ( $408.4-453 \mathrm{mbsf})$ consists of white bioclastic grainstone and rudstone alternating with levels of pinkish shades of the same lithology. The grain size of the particles ranges from sand to granule; sorting is usually good. The fauna is dominated by bryozoans, coralline algae, and larger foraminifers. Echinoderms, mollusks, and small branching corals are of secondary importance. Sandstone pebbles occur at the base of the unit. The seismic basement (Unit VII), encountered at a depth of $453 \mathrm{mbsf}$, consists of foliated quartzofeldspathic metasandstone and metasiltstone (see Feary et al., this volume).

\section{MICROFACIES ANALYSIS}

The microfacies analysis of lithified carbonates encountered at Site 824 is based on quantitative analysis of biogenic associations and sedimentary structures. Four microfacies types were found (Fig. 2, Table 1) and are described as follows:

\section{MF1: Larger Foraminifer-Bioclast Facies}

This microfacies type consists of wackestone/floatstone with microbioclastic matrix (50\%-60\%). Larger foraminifers-including mainly Miogypsina (Fig. 3), lepidocyclinids, and soritids (10\%)clearly dominate over molds after broken aragonitic mollusks (5\%). Minor constituents (in decreasing order) are calcitic bivalves, small gastropods and fragments of encrusting and articulate corallinaceans, 


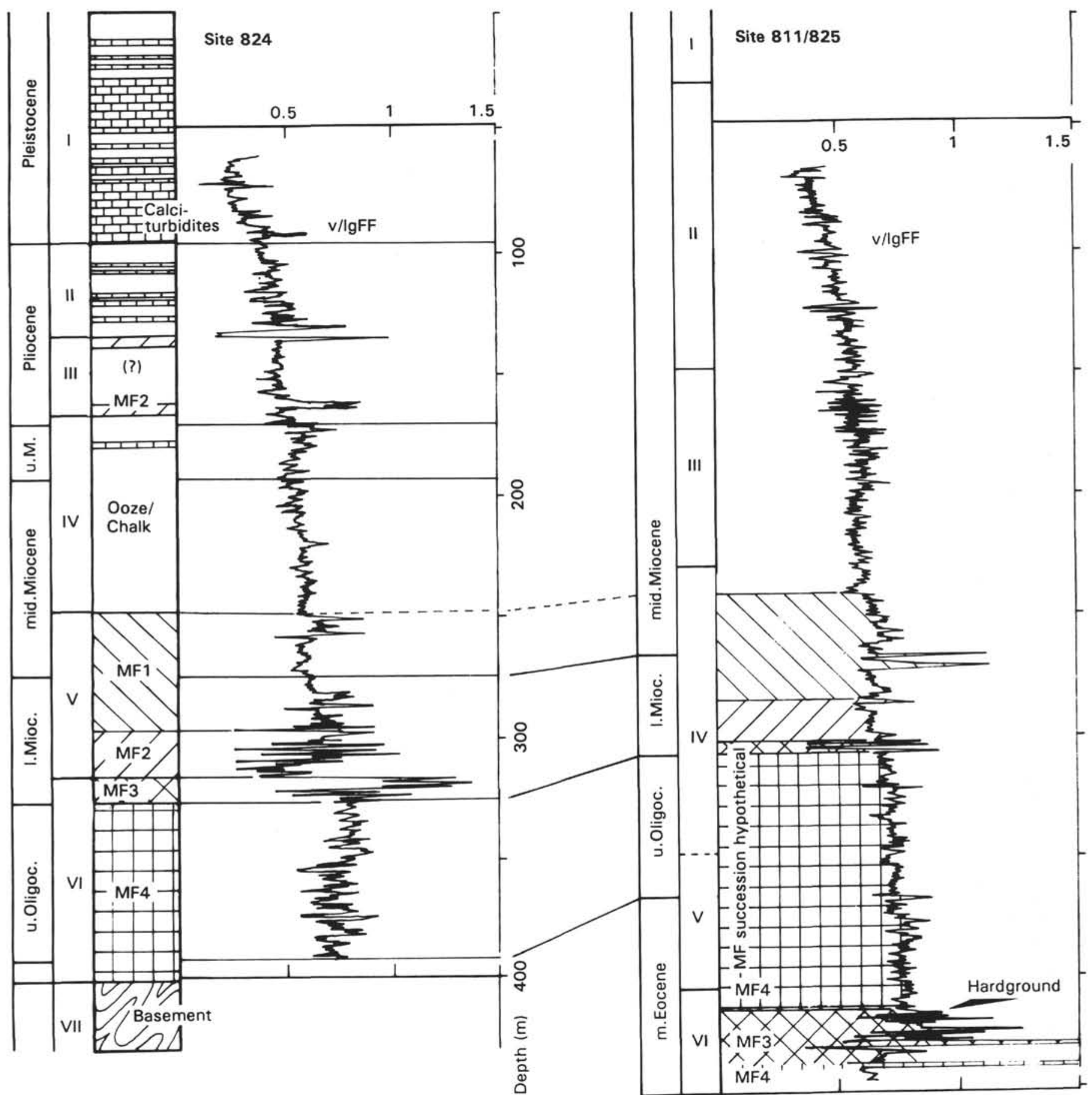

Figure 2. Lithologic successions encountered at Sites 824 and 825. MF1 and MF2 represent tropical neritic "chlorozoan" facies. MF3 represents well-cemented, subtropical bryozoan-foraminifer facies, and MF4 represents temperate-latitude bryozoan facies. Down to 379 mbsf, the succession of microfacies at Site 825 is primarily based on well-log data (v/lgFF). Lithologic units in roman numerals (after Davies, McKenzie, Palmer-Julson, et al., 1991).

cidaroid spines, some encrusting bryozoans, ostracods, few planktonic foraminifers, and some plates of Halimeda (Sample 133-824C$8 \mathrm{R}-1,51-56 \mathrm{~cm}$ ). Miliolid foraminifers (Fig. 4) are abundant in several thin sections (133-824A-29X-CC, 0-18 cm). Coral fragments found in one thin section (133-824A-10X-1, 120-124 cm) exhibit crusts of corallinacean algae and encrusting foraminifers (Gypsina).

Moldic porosity is well defined, showing smooth outlines and formed after mollusks (bivalves and gastropods) of presumably aragonitic composition (Figs. 3 and 4). Irregular voids may have formed after indeterminable bioclasts or in places may have a depo- sitional origin (Sample 133-824C-6R-CC, 0-10 cm). Cement infilling intraparticle porosity is of minor importance.

\section{MF2: Scleractinian-Corallinacean Microfacies}

This well-cemented bioclastic grainstone or rudstone is characterized by the presence of rounded and angular fragments of branching scleractinian corals ( $15 \%$ to $25 \%)$. Scleractinians are present in all samples (Fig. 5), but were not met during counting everywhere (thin section 133-824A-29X-CC, 0-18 cm). Foraminifers, including larger 
Table 1. Microfacies analyses and list of thin sections studied.

\begin{tabular}{|c|c|c|}
\hline Analysis no. & $\begin{array}{l}\text { Sample no, of thin } \\
\text { sections studied }\end{array}$ & Age \\
\hline \multirow[t]{6}{*}{ MFI } & $133-824 \mathrm{~A}-10 \mathrm{X}-1,120-124 \mathrm{~cm}$ & \multirow{14}{*}{ Paleocene } \\
\hline & 133-824B-IR-CC, $1-6 \mathrm{~cm}$ & \\
\hline & 133-824C-6R-CC, $0-10 \mathrm{~cm}$ & \\
\hline & $133-824 \mathrm{~A}-28 \mathrm{X}-\mathrm{CC}$ & \\
\hline & 133-824A-29X-CC, $0-18 \mathrm{~cm}$ (a) & \\
\hline & 133-824A-29X-CC, $0-18 \mathrm{~cm}$ (b) & \\
\hline \multirow[t]{8}{*}{ MF2 } & 133-824A-29X-CC, $0-18 \mathrm{~cm}$ & \\
\hline & $133-824 \mathrm{C}-8 \mathrm{R}-01,0-4 \mathrm{~cm}$ & \\
\hline & $133-824 \mathrm{C}-8 \mathrm{R}-01,4-9 \mathrm{~cm}$ (DS 13) & \\
\hline & $133-824 \mathrm{C}-8 \mathrm{R}-01,30-33 \mathrm{~cm}$ & \\
\hline & $133-824 \mathrm{C}-8 \mathrm{R}-01,54-50 \mathrm{~cm}$ & \\
\hline & $133-824 \mathrm{C}-8 \mathrm{R}-01,51-56 \mathrm{~cm}$ & \\
\hline & $133-824 \mathrm{~A}-30 \mathrm{X}-\mathrm{CC}, 0-17 \mathrm{~cm}$ & \\
\hline & $133-824 \mathrm{~A}-30 \mathrm{X}-\mathrm{CC}, 0-17 \mathrm{~cm}(\mathrm{a}, \mathrm{b})$ & \\
\hline \multirow[t]{8}{*}{ MF3 } & $133-825 \mathrm{~B}-6 \mathrm{R}-01,27-29 \mathrm{~cm}$ & \\
\hline & $133-825 \mathrm{~B}-6 \mathrm{R}-01,54-56 \mathrm{~cm}$ & \\
\hline & 133-825B-7R-01, $1-2 \mathrm{~cm}$ & \\
\hline & $133-825 \mathrm{~B}-7 \mathrm{R}-01,54-61 \mathrm{~cm}$ & \\
\hline & $133-825 \mathrm{~B}-7 \mathrm{R}-01,68-71 \mathrm{~cm}$ & \\
\hline & $133-825 \mathrm{~B}-8 \mathrm{R}-01,19-21 \mathrm{~cm}$ & \\
\hline & $133-824 \mathrm{C}-8 \mathrm{R}-01,61-63 \mathrm{~cm}$ & \\
\hline & $133-824 \mathrm{C}-8 \mathrm{R}-01,91-96 \mathrm{~cm}$ & \\
\hline \multirow[t]{8}{*}{ MF4 } & $133-824 \mathrm{~A}-33 \mathrm{X}-\mathrm{CC}$ & Paleocene \\
\hline & 133-824A-36X-CC, $6-9 \mathrm{~cm}$ & \\
\hline & 133-824A-36X-CC, 20-22 cm & \multirow{6}{*}{ Paleocene } \\
\hline & 133-824A-36X-CC, $26-29 \mathrm{~cm}$ & \\
\hline & 133-824A-36X-CC, 31-34 cm & \\
\hline & $133-824 \mathrm{~A}-36 \mathrm{X}-\mathrm{CC}$ & \\
\hline & 133-825B-5R-CC, 5-8 cm & \\
\hline & $133-825 \mathrm{~B}-8 \mathrm{R}-01,0-12 \mathrm{~cm}$ & \\
\hline
\end{tabular}

Note: Bold type indicates thin sections that have not been point-counted because of their poor quality.

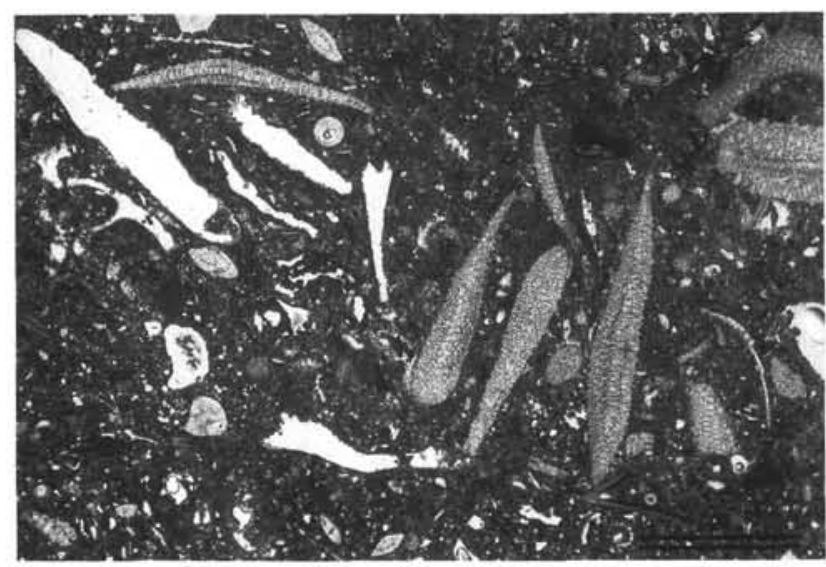

Figure 3. Larger foraminifer-bioclast facies (MF1) is a bioclastic wackestone/floatstone with abundant Miogypsina. Moldic porosity is after aragonitic biota. Scale bar $=1 \mathrm{~mm}$ (Sample 133-824B-1R-CC, 1-6 cm).

foraminifers, constitute $5 \%$ to $10 \%$ of the rock. Reworked encrusting corallinacean algae play an important role in places as fragments and encrusters of scleractinians (40\%), but commonly constitute only $5 \%$ to $15 \%$ of the rock. Isolated plates of the codiacean alga Halimeda were found sporadically, but these are not present in all thin sections.

All samples from the scleractinian-corallinacean microfacies are well-cemented carbonate rocks. Four generations of cement can be distinguished as follows:

1. The first generation of cement forms equant rims $(100 \mu \mathrm{m}$ thick) of light brown fibrous cement (Fig. 5);

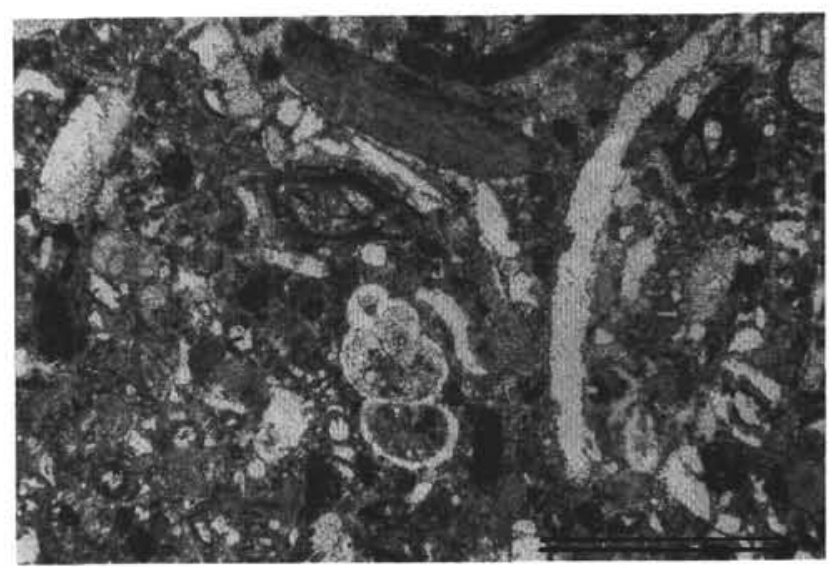

Figure 4. Larger foraminifer-bioclast facies (MF1). Miliolid foraminifers are abundant within bioclastic matrix. Thin section, scale bar $=0.5 \mathrm{~mm}$ (Sample 133-824A-29X-CC, 0-18 cm).

2. Linings of clear heterogranular to scalenohedral cement with a thickness of $200 \mu \mathrm{m}$ (Fig. 5);

3. A fine granular cement that partially fills moldic porosity after aragonitic particles, such as scleractinians. Moldic porosity after highMg-calcitic particles (miliolid foraminifers), however, remains open.

In addition, some samples exhibit the following:

4. Within some of the interparticle pores, rims of gray, homogeneous micrite (These rims post-date scalenohedral cements.). Similar to geopetal sediments, they thicken at the base of cavities, but also within corners and at the roofs of the same cavities (Fig. 5). In places, the geopetal fill is almost totally absent. This cement has been interpreted to represent vadose geofugal micrite (Aissaoui and Purser, 1983).

\section{MF3: Bryozoan-Larger Foraminifer Microfacies}

This grainstone or packstone consists of various types of bryozoans (20\% to $45 \%)$ and larger foraminifers (10\% to $40 \%$ ) (mainly Operculina, rare Nummulites) with minor amounts of corallinacean algae ( $5 \%$ to $15 \%$ ) (Figs. 6 through 9 ). The bryozoans are dominantly cheilostomes that exhibit various growth styles. They are clearly dominated by erect robust growth forms (ERro, according to the classification proposed by Nelson et al., 1988) (Fig. 6). Radiate (ERra), encrusting (ENml), and the bimineralic adeonids (N.P. James, pers. comm., 1991, ERro) are of minor importance. Bimineralic colonies also have been observed in foliaceous growth forms (ERfo). In about $70 \%$ of the bryozoans, the zoecia have very dark gray microbioclastic micritic infillings, with some globigerinid foraminifers (Figs. 6 through 8). Abraded bryozoan colonies exhibit smooth truncation of the micritic infillings (Fig. 7).

Aragonitic bivalves (1\% to $10 \%$ ) and indeterminable primary aragonitic grains occur (Fig. 10). Echinoderms (3\%), serpulids, and thick-valved ostracods are of minor importance. Although quantitatively not important, Halimeda is an important environmental indicator (Fig. 10). In association with increased marine cementation, phototrophic biota, such as corallinaceans or Halimeda (never over $1 \%$ ), and aragonitic mollusks are generally more abundant than normal, and echinoderms are absent. Partly rounded limestone lithoclasts with a maximum diameter of $2 \mathrm{~mm}$ (Fig. 6) are scattered (2\%). These represent bioclastic wackestone or microbioclastic packstone lithologies, which were found in situ only in Core 133-825B-6R-1, $54-56 \mathrm{~cm}$, filling pockets of a bored hardground. Sorting is good to medium. Bioturbated textures do occur.

Three generations of cement can be distinguished at Site 824: 


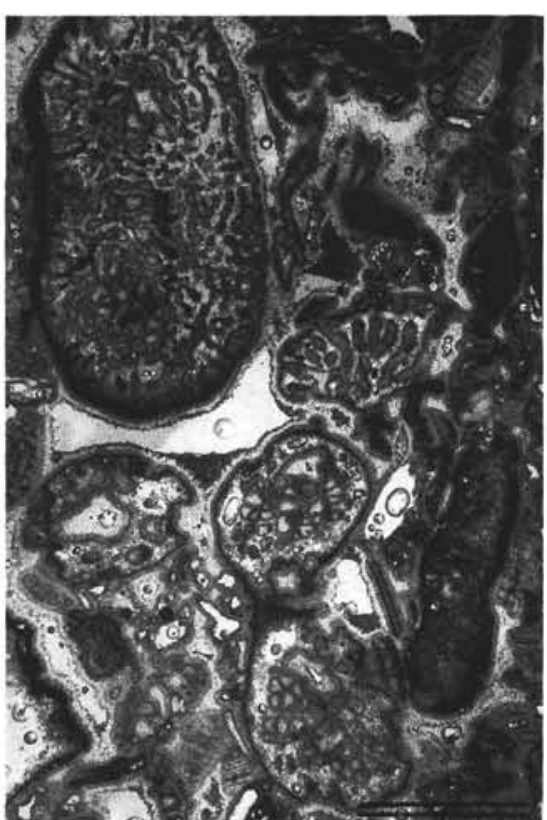

A

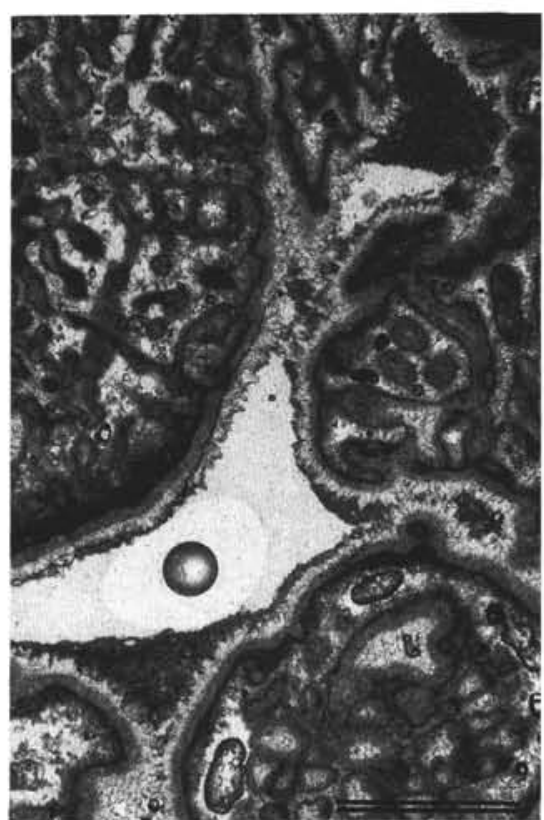

B

Figure 5. Thin section micrograph of scleractinian-corallinacean microfacies (MF2). A. Bioclastic rudstone consisting mainly of fragments of branching corals and larger foraminifers. Some of the corals exhibit red algal crusts. Scale bar $=1 \mathrm{~mm}$. B. Close-up showing cement stratigraphy: dark rims of fibrous marine cement are overgrown by clear scalenohedral cement. Geopetal and pendant, dark, clotted micrite typically forms thin seams along walls of cavities. Scale bar $=0.5 \mathrm{~mm}$ (Sample 133-824C-8R-1, 4-9 cm).

1. Equant rims (thickness, $20-30 \mu \mathrm{m}$ ) of clear, probably originally fibrous cement (Fig. 6), overgrown by

2. rims of brown, poorly preserved fibrous cement of 40 to $60 \mu \mathrm{m}$ thickness (Figs. 6 through 8 ), which is overgrown by

3. light brown to clear tips of scalenohedral calcite (size, $>50 \mu \mathrm{m}$ ) (Figs. 7, 8, 11).

As a result of recrystallization, the fibrous cement morphology has been preserved as ghosts within larger blocky crystals. These cement generations are present on echinoderm fragments, and are in optical

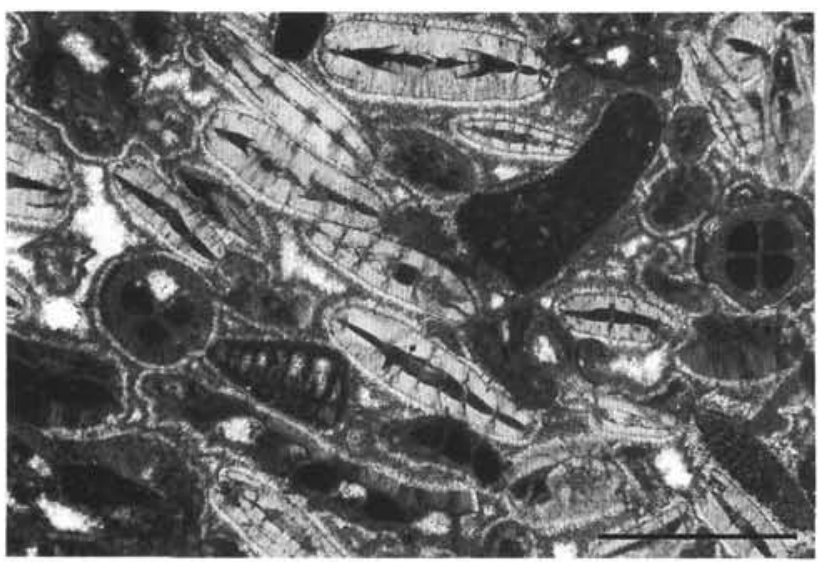

Figure 6. Bryozoan-larger foraminifer microfacies (MF3). Bioclastic grainstone consisting mainly of larger foraminifers (Operculina) and branching bryozoans (ERro) with few partly rounded limestone lithoclasts. Chambers of foraminifers and zoecias of bryozoans are filled with microbioclastic micrite. Interparticle voids are lined by two generations of equant marine cement and scalenohedral calcite cement. Scale bar $=0.5 \mathrm{~mm}$ (Sample 133-824C-8R-1, 61-63 cm). continuity with the host. The first generation of clear cement is much thicker here than elsewhere (maximum $200 \mu \mathrm{m}$ ), and the thickness of the second generation of brown fibrous cement is identical with the cements growing on other particles.

At Site 825 , there are only two generations of cement. The first is a light grayish brown rim ( $>120 \mu \mathrm{m}$ thick) of probable fibrous character (Fig. 7). The second is an irregular rim (30-100 $\mu \mathrm{m}$ thick) of clear scalenohedral cement (Fig. 8). Some of the interparticle void spaces have been sealed by a dark gray homogeneous micrite (Sample 133-825-7R-1, 1-2 cm).

A poorly washed modification of MF3 was found in Sample $133-824 \mathrm{C}-8 \mathrm{R}-1,91-96 \mathrm{~cm}$. This is a bioclastic floatstone having high

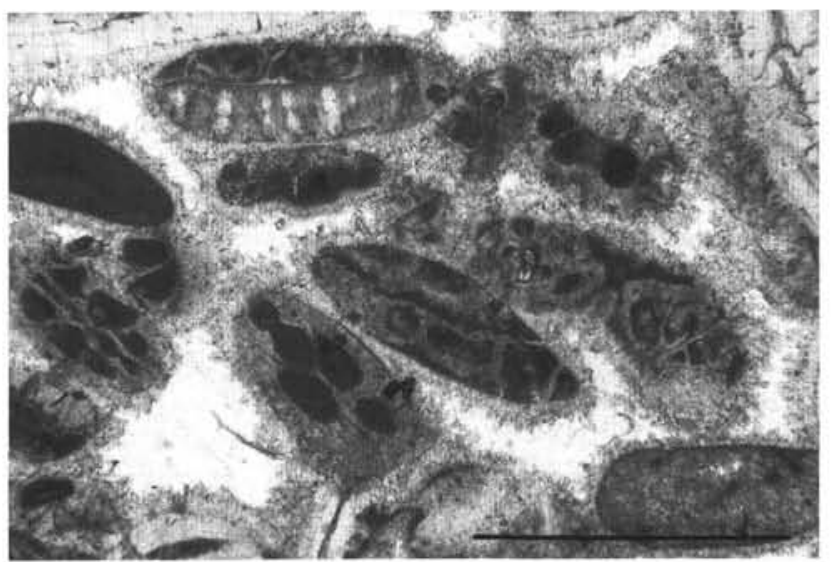

Figure 7. Bryozoan-larger foraminifer microfacies (MF3). Well-cemented grainstone composed of rounded skeletal material (bryozoans, foraminifers, corallinaceans). Note smooth truncation of skeletal particles and micritic infillings of intraparticle voids. Scale bar $=0.5 \mathrm{~mm}$, (Sample 133-825B-8R-1, 27-29 cm) 


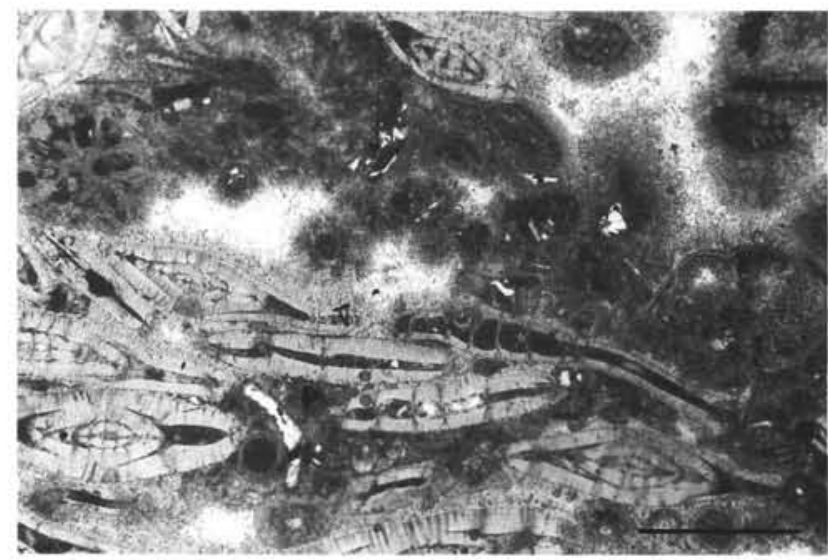

Figure 8. Bryozoan-larger foraminifer microfacies (MF3). Well-cemented grainstone showing early marine fibrous cement and a second generation of scalenohedral calcite. Scale bar $=0.5 \mathrm{~mm}$ (Sample 133-825B-7R-1, 68-71 cm).

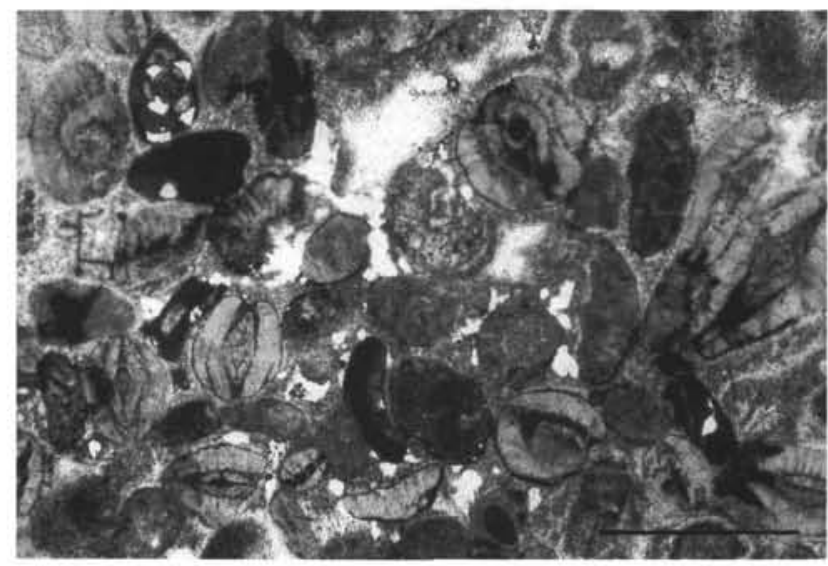

Figure 9. Bryozoan-larger foraminifer microfacies (MF3). Abraded foraminifers with dark, surficial coatings are interpreted as relict grains. Note partial dissolution of miliolid foraminifers. Scale bar $=0.5 \mathrm{~mm}$ (Sample 133-825B$8 \mathrm{R}-1,19-21 \mathrm{~cm})$.

amounts of terrigenous clastics (13\%) and large grains with micritic envelopes. The latter grains are preserved as molds. Some of them can be related to bivalves, whereas others may represent fragments of scleractinian corals. The bryozoans have increased numbers of encrusting $(\mathrm{ENml})$ colonies. Sorting is poor, with a maximum grain size of $6 \mathrm{~mm}$.

Cementation of interparticle porosity is weak or may be absent. It is more common within intraparticle pores, where it forms irregular rims (mean thickness, $100 \mu \mathrm{m}$ ) of scalenohedral calcite. Primary aragonitic particles such as adeonid bryozoans, bivalves, and large, indeterminable grains - presumably scleractinians - form voids that have cloudy rims (several hundred micrometers thick) of heterogranular mosaic cements (size $20-100 \mu \mathrm{m}$ ) developed.

\section{MF4: Bryozoan Microfacies}

The bryozoan microfacies is characterized by abundant bryozoans ( $30 \%$ to $45 \%)$ and by the scarcity of micritic matrix (few percent) (Figs. 12 through 16). The depositional texture ranges from packstone to grainstone. Indeterminate bioclasts are abundant in places $(<30 \%)$ and may have derived from bryozoans. Echinoderm remains (spines, isoplated plates, $5 \%$ to $10 \%$ ) (Fig. 14) and foraminifers (Fig. 13) occur

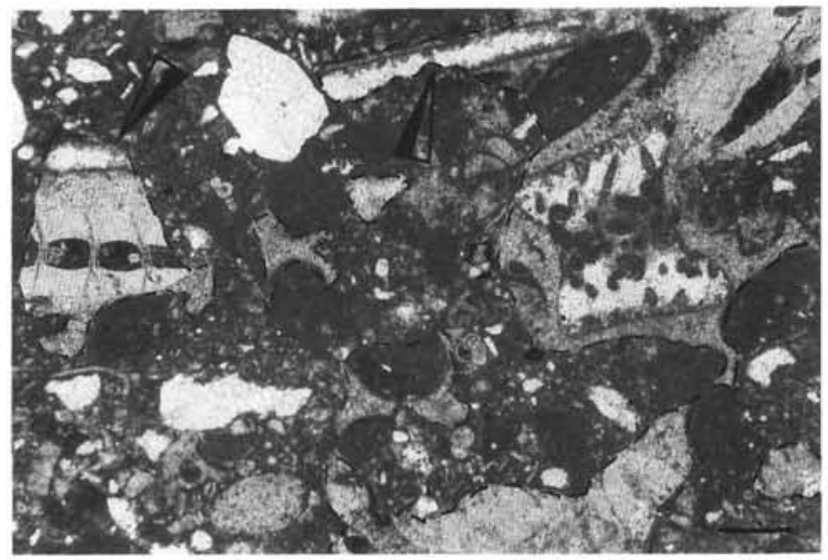

Figure 10. Perforated hardground (dotted line) formed on bryozoan-larger foraminifer microfacies (MF3). The borings are filled with bioclastic wackestone having abundant planktonic foraminifers. Borings truncate particles (larger foraminifers, bryozoans) and early marine cement. Arrows show where the infilling sediment does not occur within molds after former aragonitic bivalve, indicating that dissolution post-dates formation of hardground. Note fragment of Halimeda plate. Scale bar $=0.1 \mathrm{~mm}$ (Sample 133-825B-6R-1, $54-56 \mathrm{~cm})$.

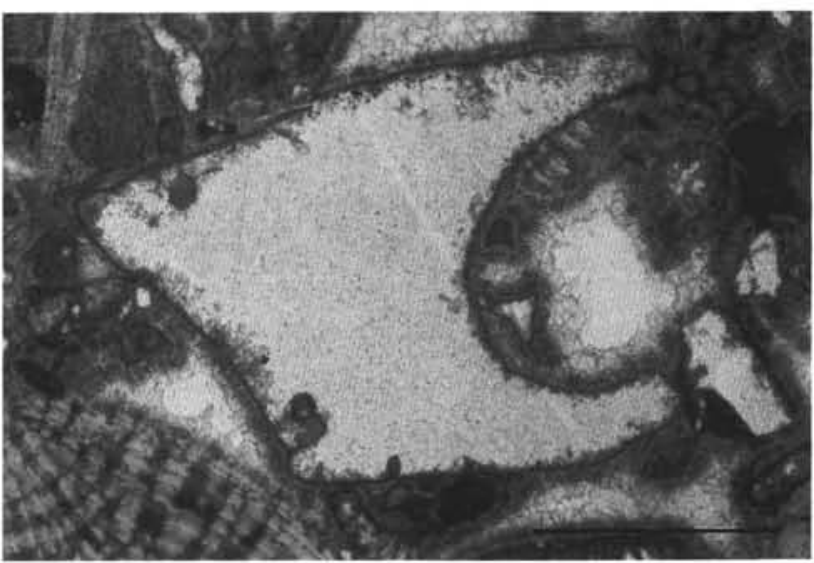

Figure 11. Mold after skeletal fragment. Early marine fibrous cement occurs only in interparticle pores. Scalenohedral cement is found in both interparticle and moldic porosities. Scale bar $=0.5 \mathrm{~mm}$ (Sample $133-824 \mathrm{C}-8 \mathrm{R}-1,45-50 \mathrm{~cm}$ ).

subordinately $(<5 \%)$. Calcitic and aragonitic mollusks are minor. Corallinaceans, both encrusting and articulated forms, are scattered.

According to the terminology proposed by Nelson et al. (1988), the bryozoans are most commonly erect forms, but encrusting colonies also exist. Free-living and erect flexible growth forms were not observed. Commonly, the bryozoans consist of rounded fragments down to indeterminable bioclasts. In many of the bryozoans, the zoecia are filled with brown microbioclastic wackestone containing abundant small planktonic foraminifers (Fig. 13). This infilling may occur within all zoecia, within some of the zoecia, or may be absent (Fig. 15). Because of extensive reworking of the bryozoan colonies before final deposition, the walls of the zoecia and the infill are often abraded or bioeroded. Rounded particles in the size of the bryozoan zoecia (which consist of bioclastic wackestone with planktonic foraminifers) are of local importance (Fig. 13). These have been interpreted to represent reworked infillings of bryozoan chambers.

The bryozoan microfacies is only weakly cemented and exhibits strong mechanical and chemical compaction. Many of the bryozoans 


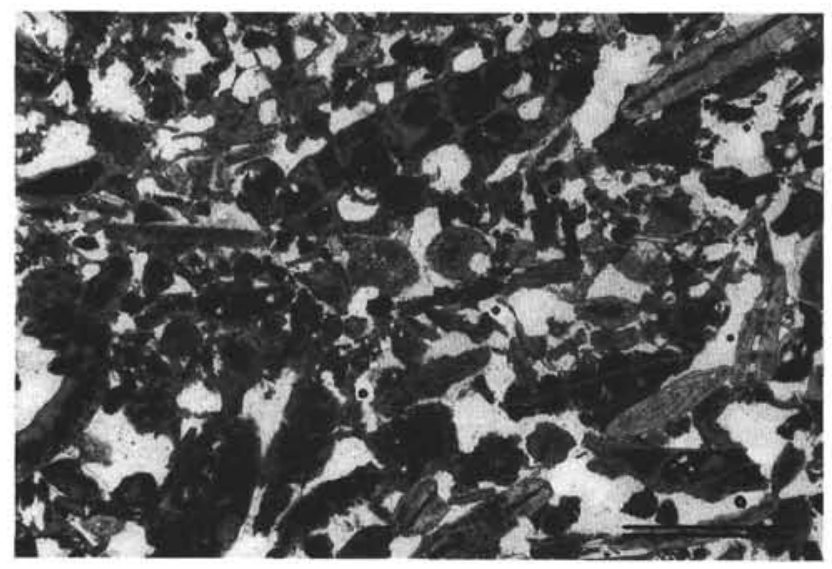

Figure 12. Bryozoan microfacies (MF4). Poorly cemented grainstone with abundant bryozoans, larger foraminifers, and echinoderms. Scale bar $=1 \mathrm{~mm}$ (Sample 133-824A-36X-CC, 20-22 cm).

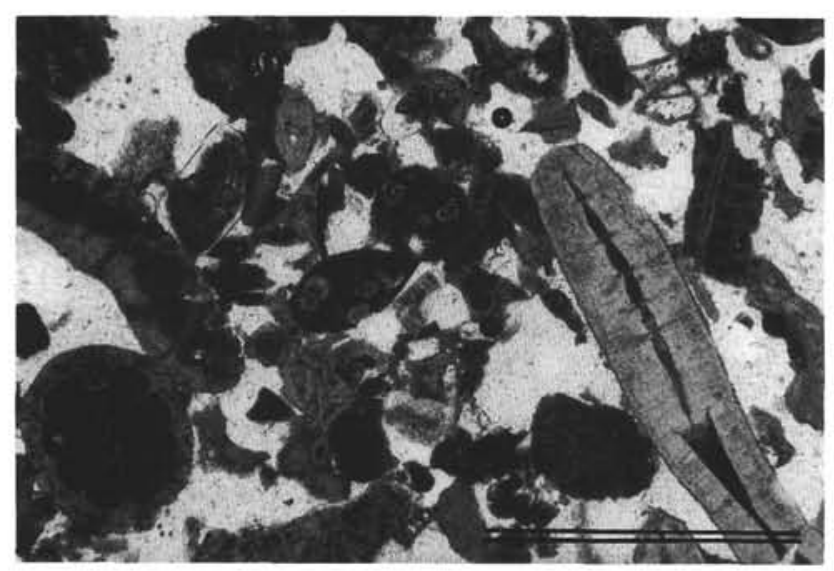

Figure 13. Detailed view of bryozoan microfacies (MF4). Microbioclastic micrite infilling intraparticle pores contain numerous planktonic foraminifers. Rounded micritic grains (center) are interpreted to represent reworked infillings of skeletal porosity. Scale bar $=0.5 \mathrm{~mm}$ (Sample 133-824C-8R-1, 61-63 cm).

are simply fractured by mechanical compaction or, in the case of delicate colonies, destroyed due to collapse of the zoecia (Fig. 15). The latter phenomenon often inhibits the recognition of bryozoan types or the proper counting of allochem types for statistical analysis. Robust growth forms or colonies having micritic infillings within their zoecia exhibit less breakage, but show dissolution fabrics at grain contacts (Fig. 16).

Syntaxial overgrowths on echinoderms are the prominent cement (Fig. 13), particularly at Site 825, and are often idiomorphic (Fig. 14), whereas thin pore linings of fine granular cement are only obvious under polarized light.

\section{DISCUSSION}

\section{Depositional Environments of MF1 and MF2}

\section{Climate}

The depositional environments encountered at Site 824 in lithified carbonates from $247.61 \mathrm{mbsf}$ downward reflect a distinct unidirectional trend from MF1 toward MF4. By analogy with the present-day GBR, the benthic assemblages described from MF1 (larger foraminifer-bioclast facies) and MF2 (scleractinian-corallinacean micro-

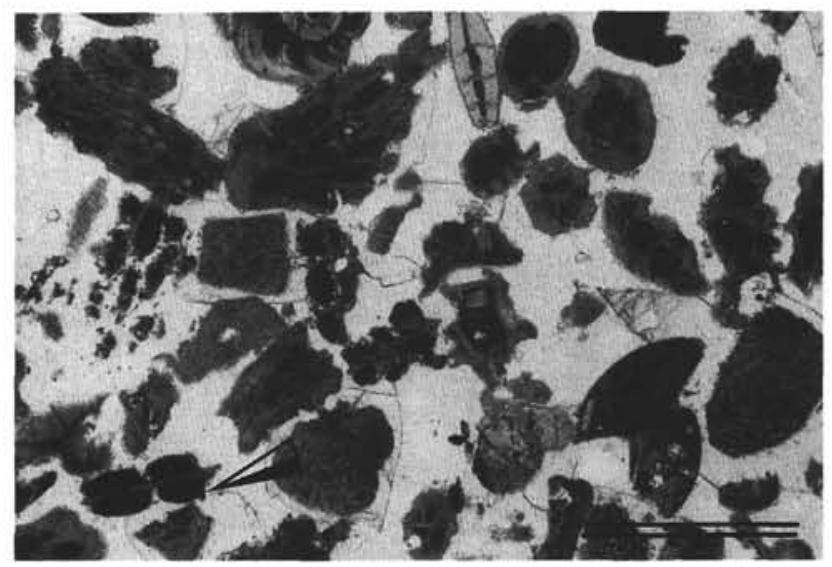

Figure 14. Bryozoan microfacies (MF4). Prominent cements are syntaxial overgrowths on echinoderm remains. In bimineralic, adeonid bryozoans, the aragonitic part of the skeleton has been dissolved, whereas the calcitic axis has been preserved. Micritic intraparticle fills are directly bounded by echinoderm rim cements (arrows). Scale bar $=0.5 \mathrm{~mm}$ (Sample 133-825B-8R-1, 0-12 cm).

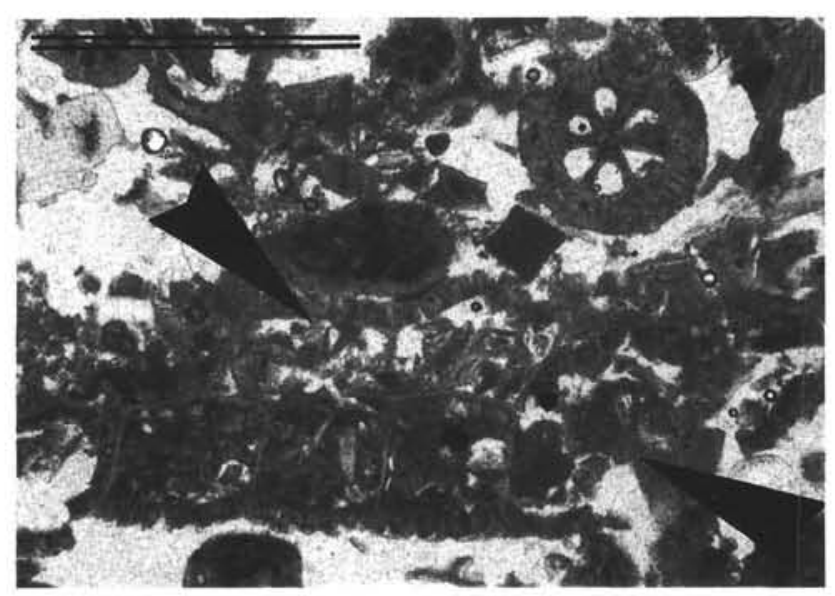

Figure 15. Mechanical compaction in bryozoan microfacies (MF4). Fragile foliate bryozoan colony is preserved only where intraparticle pores have been stabilized by microbioclastic infills. Zoecia lacking such infills are collapsed (arrows). Scale bar $=0.5 \mathrm{~mm}$ (Sample 133-824A-36X-CC, 6-9 cm).

facies) represent a tropical assemblage. Such chlorozoan assemblages (Lees and Buller, 1972) are characterized by the presence of green algae and scleractinian corals. Among the chlorophyceans, the codiacean Halimeda is an index species for tropical climates under open-ocean conditions of the northeastern Australian continental margin (Maxwell, 1973), although it has been reported to occur in less abundance at subtropical latitudes (McKenzie et al., 1980; Flügel, 1988). Halimeda was found within all samples of the scleractiniancorallinacean microfacies (MF2) and within some specimens of the larger foraminifer-bioclast facies (MF1). Because calcareous green algae are the most important producers of fine-grained carbonate mud in shallow lagoons, the presence of muddy lithologies in MF1 also may be interpreted as indication of warm waters (Nelson et al., 1988). Nonskeletal carbonate particles, such as ooids, aggregates, and peloids, typify tropical climatic zones (Lees and Buller, 1972), but are not necessarily present in tropical carbonate sediments, such as the modern GBR, where ooids are scarce (Davies and Martin, 1976; Flood, 1983; Maxwell, 1973). Thus, their absence from our samples, except for the presence of some peloids, gives no clear paleoclimatic hint. 


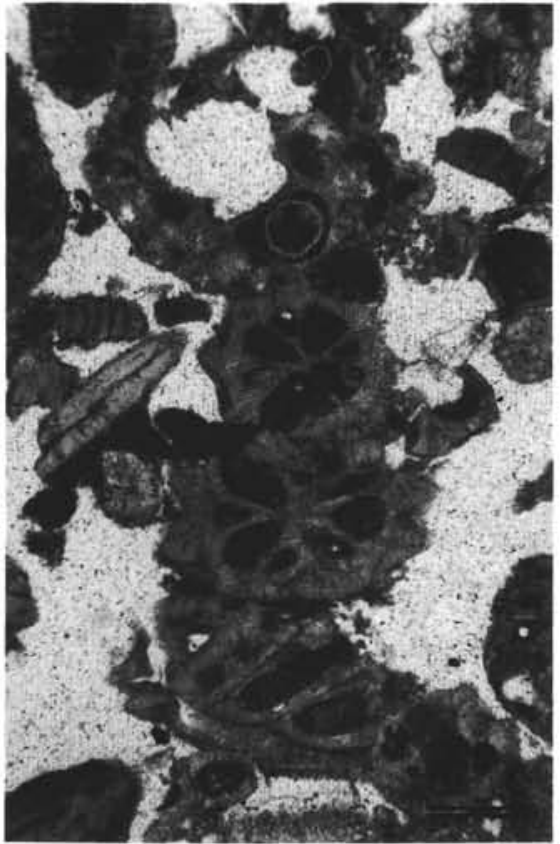

Figure 16. Dissolution at grain contacts, bryozoan microfacies (MF4). Scale bar $=0.1 \mathrm{~mm}$ (Sample 133-824A-36X-CC).

\section{Depth of Deposition}

According to the biotic compositions, MF1 and MF2 could have been deposited in either a back-reef setting or a fore-reef environment. MF1 has been interpreted as a deeper lagoonal setting with normal marine salinities that has formed behind a protective sill. The presence of muddy lithologies and the occurrence of small foraminiferal algal nodules several millimeters in diameter may indicate depths of deposition below wave base in some tens of meters of water depth (Reid and Macintyre, 1988). The abundance of miliolid foraminifers (Fig. 4) in some samples suggests temporarily restricted conditions (Chaproniere, 1975). In MF2, the scarcity of micrite and the rounding of coarse grains indicate this facies represents a fore-reef setting of moderately high energy.

\section{Depositional Environments of MF3 and MF4}

Current deposition of bryozoan carbonates is known from tropical deep waters (Reiss and Hottinger, 1984; Carannante et al., 1988) and from high-latitude shelves (Nelson, 1988; Nelson et al., 1988). According to Lees and Buller (1972), the presence of nonskeletal particles (such as ooids, grapestones, peloids and intraclasts) is indicative of warm waters. None of these particles have been found in our samples of MF3 and MF4, which indicates that both of these microfacies types may have formed in a nontropical setting.

Because of reduced rates of carbonate production with respect to the tropics, cool-water carbonates only accumulate in areas of low siliciclastic dilution (Nelson, 1988). Thus, isolation of the Queensland Plateau from mainlands, as confirmed by seismic lines (Davies, McKenzie, Palmer-Julson, et al., 1991), has been an important prerequisite for cool-water carbonates to form.

The assumption of a cool-water origin for MF3 and MF4 is supported by comparisons with published examples of modern and ancient cool-water carbonates (Nelson, 1988; Nelson et al. 1988; Collins, 1988). Particularly, fossil examples of similar age described from southern Australia (Reeckmann, 1988; James and Bone, 1989, 1991; James and von der Borch, 1991) exhibit a similar biotic composition and almost identical patterns of diagenetic alteration and cementation. The absence of a micritic matrix is a typical phenomenon of many cool-water carbonates. In contrast to the tropics, no neritic producers of aragonite mud are present, and, in cases of undersaturation of seawater, the mud fraction resulting from biogenic grain infestation undergoes rapid dissolution (Nelson et al., 1988).

\section{Depth of Deposition}

In modern cool-water carbonates, the growth style of living bryozoan colonies is controlled by environmental parameters, such as substrate, water energy, sedimentation rate, and water depth (Nelson et al., 1988). Although most of these factors are related to water depth, they are difficult to deduce from the composition of sediments or rocks because of permanent mixing of grains through reworking by storm action or tidal currents and mixing with relict grains (e.g., Pleistocene age in Holocene cool-water carbonates; Nelson et al., 1988). Generally, however, erect robust (ERro) and erect delicate (ERde) growth forms are predominant in MF4, which may be taken as an indication of a middle-shelf environment. However, some forms are indicative of shallower waters (ERml). In MF3, encrusting growth forms $(\mathrm{ENml})$ are more conspicuous, which may indicate somewhat shallower conditions than for MF4 (Nelson et al., 1988).

Most of the bryozoan zoecia exhibit microbioclastic infill rich in planktonic foraminifers, which is absent in interparticle voids. This micrite originally was interpreted as cement by Reeckmann (1988). Because skeletal material is continually being reworked by currents, we interpreted the bryozoans, which exhibit such infillings, as being exhumed from a muddy sediment ("wackestone"). Abrasion and rounding affects both the bryozoans and the infill (Fig. 7), indicating the infill was lithified before winnowing. Lithification of the infill before burial in MF4 is also evident through the absence of compaction structures in bryozoans showing such infills (Fig. 16). The contemporaneous absence of infills in some zoecias of the bryozoan colonies may not necessarily be indicative of "fresh" taphozoenoses, but may be the result of mixing of grains of different ages or may be from washing out of the infill if unlithified during exhumation. Preferential cementation within zoecias through microbial cementation processes or burial within muddy sediments for a longer period of time may be responsible for this lithification, although we have no evidence for either process.

Some of the sedimentary features common to MF4 (see above), such as the presence of abundant reworked skeletal material (foraminifers, bryozoans, both with micritic infillings) including relict particles (Fig. 9) and carbonate lithoclasts (Fig. 6), also characterize MF3. Similarly, nonskeletal grains (pellets, aggregates, ooids) are not documented and indicate rather cool-water conditions. Extensive early marine cementation and the predominance of larger foraminifers and corallinaceans over bryozoans suggest, however, that the bryozoan-larger foraminifer microfacies (MF3) exhibits a shallower and a warmer water aspect. Encrusting bryozoans (ENml), which may indicate turbulent waters, are more common than in MF4. The presence of a few isolated plates of Halimeda (Fig. 10) indicates warmerwater conditions, and MF3 is interpreted here informally as a "subtropical" limestone.

Lees and Buller (1972) originally proposed the name "foramol association" for nontropical benthic assemblages because foraminifers and mollusks were regarded as typical constituents of this temperature/salinity field. Because in many places, such as the New Zealand shelf, bryozoans are the dominant biota, Nelson et al. (1988) proposed the term "bryomol assemblage" for this type of bioclastic sediment. An important prerequisite in these examples from the Southern Hemisphere is high productivity of the surface water. Evidence for high productivity during the Oligocene that controlled the occurrence of austral bryozoan limestones is suggested by the appearance of the first baleen whales, which possess a filter feeding system that allows them to crop plankton (Fordyce, 1977, 1980). 


\section{Diagenesis}

In both sites, fibrous early marine cement was not documented in cool-water carbonates of MF4. One sample of MF3 (133-825B-6R01, 54-56 cm) exhibits extensive bioerosion by "worms" (i.e., borings of irregular shape and with ragged surfaces), which suggests early cementation on the seafloor. These borings truncate particles and fibrous cements (Fig. 10). Thus, the fibrous cements found in MF3 have been interpreted as marine precipitates.

The borings of the hardground have been completely sealed by microbioclastic wackestone or packstone containing abundant small globigerinids and delicate bryozoans. This infill does not occur within current partially cemented moldic porosity, even if truncated (Fig. 10). Thus, the dissolution of aragonite postdates the formation of the hardground and does not correlate with the occurrence of early marine cement (for another view, see Nelson, 1978) and, furthermore, the hardground represents a marine sedimentary discontinuity.

In our samples from tropical and nontropical carbonates, molds after aragonitic particles such as gastropods lack any marine cements. Instead, they show rims of dogtooth cement, which in interparticle pores form a second generation of cement on fibrous marine cement (Figs. 7, 8, 11). More commonly, moldic pores have been healed by fine, granular spar (Fig. 11), which was never found in interparticle pores. Mold-filling cements and syntaxial echinoderm rim cements (Fig. 14) are interpreted as freshwater precipitates. The latter is the only obvious cement seen in MF4. The fibrous marine cement forming the first generation of cement in MF3 was not dissolved during the dissolution of aragonite grains (Fig. 10), but the fibrous shape of the crystals has been partly destroyed because of recrystallization. Therefore, we assume a primary $\mathrm{Mg}$-calcite cement.

\section{Vertical Distribution of Microfacies}

\section{Climate}

Within the cores recovered, the microfacies types defined above show distinct vertical successions. At Site 824 (Fig. 2), the larger foraminifer-bioclast facies (MF1) was found in thin sections taken from Unit III and the upper part of Unit V (247.6 mbsf to $300.2 \mathrm{mbsf}$ ), followed by scleractinian-corallinacean microfacies (MF2) from 309.9 mbsf downward to $315.61 \mathrm{mbsf}$ and in $319.5 \mathrm{mbsf}$ of Unit V. A short interval of bryozoan-larger foraminifer microfacies (MF3) was found from 315.71 mbsf to 316 mbsf in Unit V. Unit VI consists of bryozoan microfacies (MF4), which was found from about 350 mbsf to 392.2 mbsf. This was interpreted as reflecting a warming-upward trend, beginning with late Oligocene cool-water carbonates that grade into a thin zone of subtropical deposits at the base of the lower Miocene, which was topped by a tropical carbonate platform during the later early Miocene. Abrupt warming at the base of the Miocene also was shown by McKenzie et al. (1980) and Feary et al. (1991).

At Site 825 coring began at a depth of 379 mbsf. Despite low recovery, the core from Site 825 , which is about the same age as that from the bottom of Site 824, shows an inverted succession of microfacies (Fig. 2). Bryozoan microfacies (MF4) was found in one sample at 408.45 mbsf. Underlying it was bryozoan-larger foraminifer microfacies (MF3) from 418.27 to 437.80 mbsf. This upward cooling trend occurs at the middle Eocene.

According to downhole log data, drilling at Sites 824 and 825 penetrated similar lithological successions (Fig. 2). Thus, the EoceneMiocene succession of microfacies at both sites reflects cooling and subsequent warming. For this reason, this pattern does not simply compare with the northward drift of the Australian Plate, but clearly demonstrates strong interference with short incurrences of warmer waters (McGowran, 1985) or of long-term global climatic cycles (Fig. 17). As a result of drift, however, in more southern parts of Australia (Eucla Platform), cool-water conditions lasted longer, until the early/middle Miocene boundary (James and Bone, 1991).

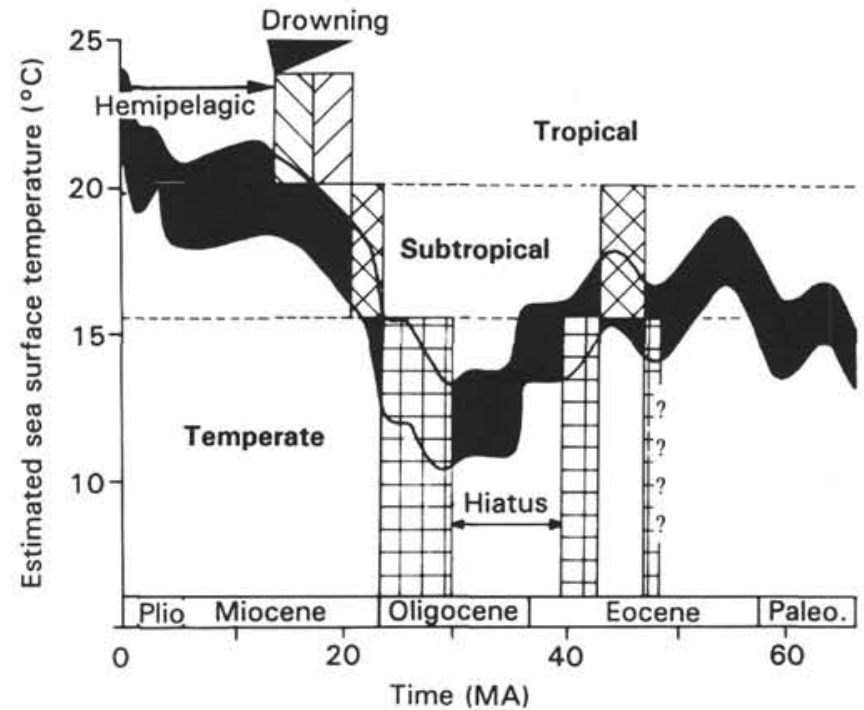

Figure 17. The vertical succession of climatically significant microfacies (rectangular boxes) reflects the variation of oxygen isotopic surface-water temperatures (black ribbon) of the present-day GBR province (corrected for the northward drift of the Australian Plate, from Feary et al., 1991). For microfacies symbols, see Figure 2.

\section{Sea Level}

In modern cool-water carbonates, sediment particles are permanently reworked and swept basinward along gently inclined slopes, where the particles mix with autochthonous skeletal particles. Two main facies zones occur (Nelson et al., 1988, James and von der Borch, 1991): the zones above and below particle winnowing. Above this base level ( 0 to $80 \mathrm{~m}$ depth) the sediments consist of coarse "skeletal hash" and some relict particles. Below, the deposits are formed by muds rich in planktonic material and some benthics, which decrease in number with depth.

According to the model proposed by James and Bone (1991), wave-base erosion and redistribution of sediments from shallow water into deeper water and below wave base take place preferentially during lowered sea levels. Thus, the occurrence of grainstones that consist to a large part of exhumed particles winnowed from a topographically deep, muddy environment (wackestone to packstone texture) indicates a preceding lowering of the wave-base. If not entirely related to sea level, long-term fluctuations of base level also may be driven by climatic changes that control oceanic circulation and wind speeds. High-energy conditions, however, presumably relate to sea level lows, and we interpret the skeletal bryozoan carbonates of MF4 to be lowstand deposits.

A middle Eocene discontinuity found in the subtropical carbonates of Site 825 represents a bored marine hardground (Fig. 2). It contains a maximum of calcareous red algae and, therefore, may represent the shallowest section of the subtropical facies with high rates of sediment winnowing and contemporaneous sea-bed lithification. The pitted surface has been sealed with muddy limestone rich in planktonic foraminifers and bryozoans. This change in depositional style indicates a rapid rise of base level. Because this rock is similar in texture and composition to the infill in the bryozoan chambers described from MF3 and MF4, it may represent the facies from which the particles forming MF3 and MF4 were eroded during falling sea level.

As predicted by James and Bone (1989), vadose cements are only documented within two levels of tropical facies (Samples 133-824C1R-CC; 133-824C-8R, 1-4 cm; 133-824C-8R, 4-9 cm). These levels are at the lower/middle Miocene boundary and at the lower middle Miocene top of the carbonate platform. Significant lowstands of global sea level characterize both of these facies levels (Haq et al., 1988). 


\section{CONCLUSIONS}

1. Compared to present-day conditions, weakly cemented, upperOligocene bryozoan carbonates represent temperate water deposits. Well-cemented, bryozoan-foraminifer limestones with calcareous algae (including few Halimeda) are informally called "subtropical facies," and chlorophycean-scleractinian carbonates are interpreted to represent tropical platforms.

2. Cool-water bryozoan carbonates suffered minor diagenetic alteration and are interpreted to have been formed through reworking of previously deposited sediments during lowstands of sea level.

3. The sedimentary record of Sites 824 and $811 / 825$ reflects subtropical conditions during the middle Eocene (bryozoan-larger foraminifer microfacies). After a hiatus representing the late Eocene and early Oligocene, the late Oligocene was represented by coolwater carbonates (bryozoan microfacies) also known from southern Australia. Subsequent, very rapid warming during the earliest Miocene has been documented by subtropical and tropical facies.

4. Eocene to Miocene benthic carbonate assemblages drilled on the Queensland Plateau (northeastern Australia) reflect similar climatic variations to those deduced from oxygen isotopic surface-water temperatures in the southwestern Pacific Ocean. This supports the chlorozoan/brymol concept.

5. Because of the northward drift of the Australian Plate, the change from temperate to subtropical and tropical facies took place earlier than in southern Australia (Eucla Platform). Major breaks in sedimentation, however, are time-equivalent.

\section{ACKNOWLEDGMENTS}

We would like to thank Y. Bone (Adelaide) for her crash course in bryozoan classification, and N.P. James (Kingston) and F. Sarg (Houston) for valuable suggestions on an earlier draft of the manuscript. J. Martin (Granada) helped with additional thin sections. Patient lingual editing by S. Stewart (College Station) is gratefully acknowledged. Financial support was provided by the Deutsche Forschungsgemeinschaft $(\mathrm{Br} 1153 / 2-1)$.

\section{REFERENCES}

Aissaoui, D.M., and Purser, B.H., 1983. Nature and origin of internal sediments in Jurassic limestones of Burgundy (France) and Fnoud (Algeria). Sedimentology, 30:273-283.

Carannante, G., Esteban, M., Milliman, J.D., and Simone, L., 1988. Carbonate lithofacies as palaeolatitude indicators: problems and limitations. Sediment. Geol., 60:333-346.

Chaproniere, G.C.H., 1975. Palaeoecology of Oligo-Miocene larger foraminiferida, Australia. Alcheringa, 1:37-58.

Collins, L.B., 1988. Sediments and history of the Rottnest Shelf, southwest Australia: a swell-dominated, non-tropical carbonate margin. Sediment. Geol., 60:15-49.

Davies, P.J., and Martin, K., 1976. Radial aragonite ooids, Lizard Island, Great Barrier Reef, Queensland, Australia. Geology, 4:120-122.

Davies, P.J., McKenzie, J.A., Palmer-Julson, A., et al., 1991. Proc. ODP, Init. Repts., 133: College Station, TX (Ocean Drilling Program).

Davies, P.J., Symonds, P.A., Feary, D.A., and Pigram, C.J., 1987. Horizontal plate motion: a key allocyclic factor in the evolution of the Great Barrier Reef. Science, 238:1697-1700.

1989. The evolution of the carbonate platforms of northeast Australia. Spec. Publ.-Soc. Econ. Paleontol. Mineral., 44:233-258.

Feary, D.A., Davies, P.J., Pigram, C.J., and Symonds, P.A., 1991. Climatic evolution and control on carbonate deposition in Northeast Australia. Palaeogeogr., Palaeoclimatol., Palaeoecol., 89:341-361.

Flood, P.G., 1983. Coated grains from the Great Barrier Reef. In Peryt, T. (Ed.), Coated Grains: Berlin (Springer), 561-565.

Flügel, E., 1982. Microfacies Analysis of Limestones: Berlin (Springer-Verlag).
1988. Halimeda: palaeontological record and palaeoenvironmental significance. Coral Reefs, 6:123-131.

Fordyce, R.E., 1977. The development of the circum-Antarctic current and the evolution of the Mysticeti (Mammalia: Cetacea). Palaeogeogr., Palaeoclimatol., Palaeoecol., 21:265-271.

1980. Whale evolution and Oligocene southern Ocean environments. Palaeogeogr., Palaeoclimatol., Palaeoecol., 31:319-336.

Hallock, P., and Schlager, W., 1986. Nutrient excess and the demise of coral reefs and carbonate platforms. Palaios, 1:389-398.

Haq, B.U., Hardenbol, J., and Vail, P.R., 1987. Chronology of fluctuating sea levels since the Triassic. Science, 235:1156-1167.

James, N.P., and Bone, Y., 1989. Petrogenesis of Cenozoic temperate water calcarenites, south Australia: a model for meteoric/shallow burial diagenesis of shallow water calcite sediments. J. Sediment. Petrol., 59:191-204.

, 1991. Origin of a cool-water, Oligo-Miocene deep shelf limestone, Eucla Platform, southern Australia. Sedimentology, 38:323-341.

James, N.P., and von der Borch, C.C., 1991. Carbonate shelf edge off southern Australia: a prograding open-platform margin. Geology, 19:1005-1008.

Lees, A., and Buller, A.T., 1972. Modern temperate-water and warm-water shelf carbonate sediments contrasted. Mar. Geol., 13:M67-M73.

Maxwell, W.G.H., 1973. Sediments of the Great Barrier Reef Province. In Jones, O.A., and Endean, R. (Eds.), Biology and Geology of Coral Reefs (Vol. 1). Geology, 299-345.

McGowran, B., 1985. Cainozoic oceanic and climatic events: the Indo-Pacific foraminiferal record. Palaeogeogr., Palaeoclimatol., Palaeoecol., $55: 247-265$.

McKenzie, J.A., Bernoulli, D., and Schlanger, S.O., 1980. Shallow-water carbonate sediments from the Emperor Seamounts: their diagenesis and paleogeographic significance. In Jackson, E.D., Koizumi, I., et al., Init. Repts DSDP, 55: Washington (U.S. Govt. Printing Office), 415-455.

Nelson, C.S., 1978. Temperate shelf carbonate sediments in the Cenozoic of New Zealand. Sedimentology, 25:737-771.

1988. An introductory perspective on non-tropical shelf carbonates. Sediment. Geol., 60:3-12.

Nelson, C.S., Keane, S.L., and Head, P.S., 1988. Non-tropical carbonate deposits on the modern New Zealand shelf. Sediment. Geol., 60:71-94.

Reeckmann, A.S., 1988. Diagenetic alteration in temperate shelf carbonates from southeastern Australia. Sediment. Geol., 60:209-219.

Reid, R.P., and Macintyre, L.G., 1988. Foraminiferal nodules from the eastern Caribbean: growth history and implications on the value of nodules as paleoenvironmental indicators. Palaios, 3:424-435.

Reiss, Z., and Hottinger, L., 1984. The Gulf of Aqaba: Ecological Micropalaeontology: Berlin (Springer).

Reymer, J.J.G., Schlager, W., and Droxler, A.W., 1988. Site 632: PliocenePleistocene sedimentation cycles in a Bahamian basin. In Austin, J.A., Jr., Schlager, W., et al., Proc. ODP, Sci. Results, 101: College Station, TX (Ocean Drilling Program), 213-220.

Scoffin, T.P., 1986. Introduction to Carbonate Sediments and Rocks: New York (Chapman and Hall).

\footnotetext{
-Abbreviations for names of organizations and publications in ODP reference lists follow the style given in Chemical Abstracts Service Source Index (published by American Chemical Society).
}

\section{Date of initial receipt: 7 April 1992 \\ Date of acceptance: 10 November 1992 \\ Ms 133SR-233}

\section{APPENDIX}

Because of the low recovery, the samples investigated from different holes of Site 824 were combined in one section, based on depth in the core below the seafloor. Most cores recovered consist of several isolated pieces that can only be located relatively within one core (length of core, $10.5 \mathrm{~m}$ ) but not with respect to their absolute depth downhole. For this reason, the deepest sample of Unit VB (133-824A-30X-CC, 0-17 cm), which was classified as MF2, originally may have been located relatively farther up within the unit. Thus, it presumably belongs to the upper MF2 level. The relative position of the other samples taken from Unit $\mathrm{V}$, however, seems to be clear. 